NAMA = DEWI SRI HANDAYANI

$\mathrm{NIM}=70200120121$

KELAS = KESMAS D

\title{
ANEMIA PADA IBU HAMIL
}

\section{PENDAHULUAN}

Kehamilan adalah masa ketika tubuh benar-benar perlu menjaga asupan makanan yang maksimal baik secara fisik maupun mental (untuk rileks dan bebas stres setiap saat). Wanita hamil biasanya mengeluh kelelahan, pusing, sesak nafas, wajah pucat dan keluhan lainnya. Semua keluhan tersebut menunjukkan bahwa ibu hamil menderita anemia selama kehamilan. Penyakit tersebut terjadi akibat rendahnya kandungan hemoglobin dalam tubuh selama kehamilan. Prevalensi anemia pada ibu hamil di Indonesia sangat tinggi, terhitung sekitar $67 \%$ dari seluruh ibu hamil, dan bervariasi dari satu daerah ke daerah lain. Sekitar 10$15 \%$ tergolong anemia berat, yang tentunya akan mempengaruhi tumbuh kembang janin di dalam kandungan (Manuaba, 2002) dalam (Hariati H. dkk., 2019)

Anemia selama hamil tidak lepas dari perubahan fisiologis yang terjadi selama kehamilan, usia janin, dan kondisi ibu hamil sebelumnya. Selama kehamilan, tubuh mengalami perubahan besar dan volume darah dalam tubuh meningkat sekitar 20-30\%. Oleh karena itu, produksi hemoglobin membutuhkan peningkatan pasokan zat besi dan vitamin. Selama kehamilan, tubuh ibu mengeluarkan lebih banyak darah untuk dibagikan kepada bayi. Tubuh manusia membutuhkan darah 30\% lebih banyak dibandingkan sebelum kehamilan (Noverstiti, 2012) dalam (Kadir S., 2019)

Jika tidak ditangani tepat waktu, akibat dari anemia kehamilan dapat berakibat fatal, yang dapat menyebabkan keguguran, persalinan prematur, persalinan jangka panjang, kontraksi uterus yang lemah, serta menyebabkan perdarahan dan syok. Hal ini terkait dengan banyak faktor yang mempengaruhi antara lain status gizi, usia, tingkat pendidikan dan pekerjaan (Sarwono Prawirohardjo, 2005). Dampak anemia pada hasil kehamilan dapat menyebabkan keguguran, kematian janin dalam kandungan, kematian janin saat lahir, tingginya angka kematian perinatal, persalinan prematur, dan cacat bawaan (Assis Z et al., 2014). Hasil penelitian Ridayanti (2012) menunjukkan bahwa wanita primipara dengan anemia gestasional sebanyak 44,6\%, dan primipara dengan anemia gestasional sebesar 
12,8\%. Hal ini dikarenakan ibu yang baru pertama kali hamil tidak memiliki pengalaman menjaga kesehatan pada kehamilan sebelumnya karena kehamilan pertamanya. (Farsi et al, 2011) dalam (Hariati H. dkk., 2019)

Beberapa faktor yang dapat menyebabkan anemia terkait kehamilan antara lain tingkat pengetahuan, status ekonomi, dan kepatuhan asupan zat besi. Hasil penelitian yang dilakukan oleh Ridayanti (2012) menunjukkan bahwa terdapat hubungan yang signifikan antara tingkat pengetahuan ibu hamil dengan kejadian anemia, hal ini dikarenakan tingkat pengetahuan seseorang mempengaruhi kesadaran berperilaku dalam hidup sehat dan membentuk mentalitas yang baik, sehingga Para ibu akan merasa lebih mudah. Menerima informasi dan memiliki pengetahuan yang cukup (Popa et al, 2013) dalam (Hariati H. dkk., 2019)

\section{FAKTOR ANEMIA PADA IBU HAMIL}

Anemia pada ibu hamil adalah kondisi dimana kadar hemoglobin $(\mathrm{Hb})$ darah ibu lebih rendah dari $11 \mathrm{~g} / \mathrm{dl}$. Berdasarkan data Riskedas tahun 2013, angka anemia kehamilan di Indonesia sebesar 37,1\%, sedangkan angka anemia kehamilan di Makassar tahun 2017 sebesar 7,29\%. Pada tahun 2017 terjadi penurunan jumlah kasus anemia pada ibu hamil yaitu jumlah kasus anemia pada ibu hamil mengalami penurunan $(29,1 \%$ ) (data Puskesmas Sudiang Raya, 2018). Berdasarkan data anemia ibu hamil di Puskesmas Sudanaya periode Januari-Juli 2018, jumlah ibu hamil yang ada di Puskesmas Sudanaya sebanyak 489 orang, dimana 92 kasus ibu hamil mengalami anemia dengan rasionya 18,8\% (Puskesmas Sudanaya 2018) (Syarfaini dkk ., 2019)

Wanita hamil membutuhkan zat besi untuk mencegah anemia dan menjaga pertumbuhan janin tetap optimal. Kementerian Kesehatan menganjurkan agar ibu hamil meminum setidaknya 90 pil zat besi selama kehamilan (Depkes RI, 2001). Sekitar sepertiga seng dalam tubuh manusia terikat kuat pada protein (makroglobulin), sedangkan seng yang tersisa terikat lemah pada albumin atau histidin dan asam amino sistin. Selama infeksi, anemia pernisiosa, hipertiroidisme, kehamilan dan penggunaan kontrasepsi oral, kadar seng serum akan menurun. (Syarfaini dkk ., 2019)

Dari hasil penelitian menyatakan bahwa risiko pendidikan rendah terhadap anemia ibu hamil $(\mathrm{OR}=3,00) 3$ kali lebih berisiko mengalami anemia dibandingkan pendidikan tinggi. Pengetahuan rendah terhadap ibu hamil $(\mathrm{OR}=3,46)$ 3,46 kali lebih berisiko dibandingakan 
yang memiliki pengetahuan tinggi. Asupan Fe yang kurang $(\mathrm{OR}=1,36)$ 1,36 kali lebih berisiko dibandingkan yang mempunyai asupan Fe yang cukup. Asupan zink yang kurang $(\mathrm{OR}=1,66)$ 1,66 kali lebih berisiko dibandingkan yang mempunyai asupan zink yang cukup. Kepatuhan konsumsi tablet Fe $(\mathrm{OR}=3$,22)ibu yang tidak patuh konsumsi tablet Fe 3,22 kali lebih berisiko dibandingkan ibu yang patuh konsumsi tablet Fe. Riwayat seksio sesarea $(\mathrm{OR}=1,88)$ ibu yang mempunyai riwayat seksio sesarea 1,88 kali lebih berisiko dibanding akan ibu yang tidak mempunyai riwayat seksio sesarea. Jarak kehamilan $(\mathrm{OR}=2,78)$ jarak kehamilan yang kurang 2 tahun 2,78 kali lebih berisiko dibandingkan jarak kehamilan lebih dari 2 tahun. (Syarfaini dkk ., 2019)

\section{KEKURANGAN ENERGI KRONIK}

Kekurangan energi kronik merupakan suatu kondisi yang menggambarkan status gizi seorang wanita yang dibuahi, pada kondisi tersebut seseorang kekurangan gizi, terutama sesuai dengan kebutuhan gizi individu, asupan makanan yang tidak mencukupi dapat menyebabkan terjadinya kekurangan energi. Wanita usia subur (WUS) adalah wanita dalam rentang usia di mana organ kewanitaan mulai matang dan telah bekerja normal antara usia 15-49 tahun, termasuk wanita hamil, wanita tidak hamil, ibu nifas, calon pengantin, wanita muda, Dan pekerja perempuan. Kekurangan energi kronik yang sering menyerang pada usia wanita menggambarkan asupan energi dan protein yang tidak adekuat. risiko keku rangan energi kronik pada kelompok umur wanita usia subur (Angraini, 2018) dalam (Alam S, dkk., 2020).

Gizi seimbang merupakan suatu susunan makanan sehari - hari yang mengan zat gizi dalam jenis dan jumlah yang sesuai dengan kebutuhan tubuh dan terpenuhi, dengan memerhatikan prinsip variasi makanan atau keanekaragaman, kebersihan, aktivitas fisik, dan berat badan ideal (Supariasa et al. , 2002) dalam (Alam S, dkk., 2020).

Mengenai pemenuhan gizi untuk kesehatan tubuh, pengetahuan cenderung menjadi lebih baik dan mampu memprak tekknaya dalam pemenuhi gizinya, begitu pun sebaliknya mereka dengan status pen didikan yang baik namun kurang mampu menyusun makanan yang memenuhi syaratan gizi yang inilah yang beresiko terjadinya kekurangan gizi seperti KES pada WUS. Penyebabnya bisa jadi karena pendidikan yang memadai dan peluang beraktifitas diluar rumah yang lebih besar sehingga berdampak pada beban kerja yang membuat mereka merasa lebih stres, pola hidup dan pola makan yang teratur dan teratur sehingga tidak mustahil jika kembali sponden dapat berisiko Kekurangan Energi Kronik (Kartikasari dkk ., 2012) dalam (Alam S, dkk., 2020). 
Kerurangan energi kronik yang terjadi pada wanita unsia subur sebagai akibat dari faktor tidak langsug seperti lingkungan dan faktor langsun dari individu manusia yang didukung oleh konsumsi zat gizi sesuai kebutuhan, maka zat gizi yang tersimpan dalam tubuh digunakan untuk me menuhi kebutuhan. Berdasarkan hasil penelitian menunjukkan tidak terdapat hubungan antara po la makan dan riwayat pendidikan dengan kejadian KEK pada Wanitas Usia Subur di Desa Gunturu Kab. Bulukumba. Tidak adanya hubungan bermakana secara tik tik antara pola makan dan riwayat pendidi kan dimungkinakan statistik oleh pro porsi WUS yang KEK lebih kecil yaitu 45 orang (12,5\%) bekerja sama WUS yang tidak KEK sebanyak 314 orang (85,5\%) (Alam S, dkk., 2020).

\section{ALTERNATIF PERBAIKAN GIZI}

Rumput laut lawi-lawi memiliki kandungan nutrisi yang tinggi sebagai sumber protein dan mineral nabati. Rumput laut jenis ini mengandung protein $17-27 \%$, lemak $0,08-1,9 \%$, karbohidrat $39-50 \%$, serat 1,3 -12,4\%, abu 8,15-16,9\% dan kadar air tinggi 80-90\%

( Verlaque et al., 2003 dalam Burhanuddin, 2014: 8) dalam (Syarfaini dkk ., 2019)

Untuk meningkatkan kandungan gizi produk olahan berbahan dasar rumput laut lawilawi perlu dilakukan penambahan bahan pangan lokal lain yang dapat dioptimalkan, yaitu merupakan sumber protein nabati dan kaya zat besi serta zat gizi lainnya. Padahal dibandingkan dengan protein hewani, kualitas protein nabati masih sangat rendah, namun kombinasi berbagai sumber nabati dapat memberikan efek komplementer dari asam amino esensial (Winarno, 2002, Estingtyas, 2014: 9 dalam Burhanuddin, 2014: 8) dalam (Syarfaini dkk ., 2019)

Menurut Mudjajanto dan Yulianti (2004) dalam Suryatna (2015), roti merupakan produk olahan pangan yang terbuat dari tepung terigu yang telah difermentasi dengan ragi dan ditambah dengan bahan pengembang lainnya, serta memiliki wangi atau rasa yang disukai konsumen. Lalu panggang. Berdasarkan uraian di atas, untuk mengetahui kandungan gizi peraturan perundang-undangan terkait rumput laut dan kacang tanah serta mengembangkan pangan untuk meningkatkan kebutuhan gizi masyarakat melalui pangan lokal yang terjangkau, peneliti menganalisis kandungan zat tersebut dan mengganti roti rumput laut dengan peraturan perundang-undangan. Untuk rumput laut. Undang. Roti, dengan demikian mewujudkan diversifikasi pangan lokal. Pengujian kadar air karbohidrat, protein, lemak, zat besi $(\mathrm{Fe})$, dan nutrisi sensorik merupakan salah satu alternatif perbaikan gizi masyarakat. (Syarfaini dkk., 2019). 


\section{DAFTAR PUSTAKA}

Alam, S., dkk. (2020). Eating pattern and educational history in women of childbearing age. Al-Sihah: The Public Health Science Journal, 12(1), 81-91.

Angraini, DI (2018). Hubungan Faktor Keluarga dengan Kejadian Kurang Energi Kronis pada Wanita Berusia di Kecamatan Terbanggi Besar. JK Unila, 2 (2), 146-150. https://juke.kedvements.unila.ac.id/ind ex.php / JK / article / download / 1952/191 9

Anggur Laut (Caulerpa racemosa) pada Wadah Terkontrol. Jurnal Balik Diwa. 2:8- 13

Burhanuddin. (2014). Respon Warna Cahaya terhadap Pertumbuhan dan Kandungan Karatenoid

Farsi Y., dkk. 2011. Effect of high parity on accurrence of anemia in pregnancy: a cohort study. BMC Pregnancy and Children. 11(7).

Hariati, H., dkk. (2019). Kejadian Anemia Pada Ibu Hamil. Jurnal Ilmiah Kesehatan, 1(1), 8-17.

Kadir, S. (2019). Faktor Penyebab Anemia Defisiensi Besi Pada Ibu Hamil di Wilayah Kerja Puskesmas Bongo Nol Kabupaten Boalemo. Jambura Journal of Health Sciences and Research, 1(2), 54-63.

Kartikasari BW., dkk. (2012). Hubungan Pendidi kan, paritas, dan Pekerjaan Ibu Dengan Status Gizi Ibu Hamil Tri mester III di Puskesmas Bangetayu Kecamatan Genuk Kota Semarang Tahun 2011. Jurnal Kebidanan, 1 (1), 2. https://doi.org/https://doi.org/10.26714/jk.1.1.2012.9-18

Manuaba. 2002. Ilmu kebidanan, penyakit kandungan dan KB untuk pendidikan bidan. Jakarta: EGC

Noverstiti, Elsy. (2020). Faktor-faktor yang Berhubungan dengan Kejadian Anemia pada Ibu Hamil Trimester III di Wilayah Kerja Puskesmas Air Dingin Kota Padang tahun 2012. STIKES Peringsewu Lampung.

Syarfaini, S., dkk. (2020). Faktor Risiko Kejadian Anemia Pada Ibu Hamil Di Wilayah Kerja Puskesmas Sudiang Raya Kota Makassar. Al-sihah: The Public Health Science Journal, 11(2).

Syarfaini, S., dkk. (2019). Analisis Kandungan Zat Gizi Roti Rumput Laut Lawi-Lawi (Ceulerpa racemosa) Subtitusi Tempe Sebagai Alternatif Perbaikan Gizi Masyarakat. Al-sihah: The Public Health Science Journal, 11(1).

Supariasa, dkk. (2002). Penilaian Status Gizi (2nd red.). Buku Kedoktran EGC.

Suryatna, B. S. (2015). Peningkatan Kelembutan Tekstur Roti Melalui Fortifikasi Rumput Laut Euchema Cottoni. Jurnal Teknoboga. 2:18-25. 